\title{
A PREHISTORIC BREEDING POPULATION OF HARP SEALS (PHOCA GROENLANDICA) IN THE BALTIC SEA
}

\author{
JAN STOR̊ \\ Archaeoosteological Research Laboratory, \\ University of Stockholm, \\ Royal Castle of Ulriksdal, SE-170 79 Solna, Sweden \\ E-mail: jan.stora@ofl.su.se \\ Per G. P. ERICSON \\ Department of Vertebrate Zoology, \\ Swedish Museum of Natural History, \\ P. O. Box 50007, SE-104 05 Stockholm, Sweden
}

\begin{abstract}
The pelagic and gregarious, low Arctic harp seal (Phoca groenlandica) is the most common seal species in most refuse faunas from coastal hunter-gatherer sites dating from the late Atlantic to the early Subboreal period ( $c a$. 4000-2000 cal B.C.) in the Baltic Sea. Our main objective was to examine the migration contra breeding population hypotheses regarding the Baltic harp seals. Analyses of epiphyseal fusion data and osteometry of archeological harp seal remains from 25 dwelling-sites suggest that a local breeding population established itself in the early Subboreal period. In the Middle Neolithic the rookery possibly was situated in the Baltic proper, south of Aland and west of Gotland. The mean adult size of the Baltic harp seals decreased, suggesting minimal genetic exchange with the north Atlantic Ocean population. Genetic drift, interspecific competition, and over-hunting by humans are all factors likely to have contributed to the eventual extinction of harp seals in the Baltic Sea.
\end{abstract}

Key words: Baltic Sea, harp seal, Phoca groenlandica, subboreal, Mesolithic, Neolithic.

Three species of seal inhabit the Baltic Sea today: the gray seal (Halichoerus grypus Fabricius, 1791), the ringed seal (Phoca bispida botnica Gmelin, 1788), and the harbor seal (Phoca vitulina Linnaeus 1758). In prehistoric times, a fourth species of seal occurred in the Baltic Sea-the Arctic harp seal (Phoca groenlandica Erxleben, 1777). Today, harp seals live in the northern Atlantic Ocean where they breed in huge concentrations in the pack ice in three major areas: the White Sea, around the Jan Mayen Islands, and Newfoundland (Sergeant 1991). The harp seal is pelagic, and outside the breeding season it migrates over considerable distances in large groups.

Although the harp seal probably occurred along the Swedish west coast in the Late Glacial, there is no evidence that it penetrated the Baltic Sea (Lepiksaar 1964, 
Fredén 1975). A harp seal recovered from supposedly Late Glacial layers in Stockholm (Kinberg 1869) is now believed to be from a considerably younger geological period (Fredén 1975). A younger date is also suggested on osteological grounds (Lepiksaar 1964). Instead, the oldest finds of harp seals in the Baltic Sea have been identified from Mesolithic hunter-gatherer sites in Denmark dated to $c a$. 5000-3500 cal B.C., i.e., the Atlantic chronozone (Madsen et al. 1900; Mathiassen et al. 1942; Møhl 1970, 1971; Andersen 1992, 1995). Harp seal bones of a slightly younger age have been found at human dwelling sites situated along the shores of the Baltic proper, e.g., Gotland and Estonia (Lõugas et al. 1996, Lindqvist and Possnert 1997). The species also occurs at the late Mesolithic sites of Alby on Öland and Grisby on Bornholm, (Königsson et al. 1971, 1993). Based on the archeological record, it thus seems safe to assume that the harp seal entered the Baltic Sea at the end of the Atlantic period, sometime between 5000 and $4000 \mathrm{cal}$ B.C.

In the Subboreal period (approximately between 3800-500 cal B.C.), the number of archaeological finds of harp seals increases markedly, and many remains of the species have been identified in refuse faunas from Neolithic sites in Eastern Middle Sweden, Aland islands, Gotland, and on the Swedish west coast (Holmqvist 1912; Winge 1914; Nihlén 1927; Henrici 1936; Ekman 1972, 1974; Aaris-Sørensen 1978; Lindqvist 1988; Segerberg 1999; Storå 2000, 2002). The harp seal is also common in Subboreal refuse faunas in Estonia, Latvia, Lithuania, and Poland (Lubicz-Niezabitowski 1928; Lasota-Moskalewska 1997; Lõugas 1997a, b, 1998; Daugnora 2000; Zagorska 2000). These finds reflect an extensive hunt of harp seals in the Baltic proper that is not paralleled north of $\AA$ land, where the ringed seal dominates in the coastal refuse faunas (Almgren 1906, Lepiksaar 1974, Ericson 1989, Olson 1999, Segerberg 1999).

Later in the Subboreal, at the end of the Neolithic (ca. 1800-1500 cal B.C.), the relative frequency of the harp seal at archeological sites decreases. After the Stone Age, harp seal remains have been recovered at Bronze Age sites in Estonia and Iron Age sites in Öland, Denmark and Åland (Winge 1904; Møhl 1957, 1970; Boessneck and von den Driesch 1979; Lõugas 1997a, 1998; Storå, personal observation). At present, they are far fewer in numbers, and gray seals, ringed seals, or harbor seals, depending on the geographic location of the site, dominate the refuse faunas. Some of the harp seals from later periods are considerably larger than those in the Subboreal, equalling the size of the extant population in the Atlantic Ocean (Møhl 1957), and it has been suggested that they represent sporadic invasions of the Baltic Sea (Lepiksaar 1964).

The occurrence of large numbers of the harp seals in the Baltic Sea during the warmest phase of the present interstadial, the late Atlantic and Subboreal periods, is a paradox that has caused considerable discussion (see Fredén 1984). Two main explanations have been proposed: the "migration hypothesis" that postulates that the region was regularly (annually?) visited by migrants from breeding grounds in the Atlantic Ocean (Lepiksaar 1964), and the "breeding population hypothesis" which assumes the species bred in the Baltic Sea. Holmqvist (1912) suggested the presence of a breeding Baltic population and believed it was a glacial relict. This idea of a relict population was soon abandoned, and today the "breeding population hypothesis" postulates that a breeding colony of harp seals was founded in the late Atlantic or Subboreal periods by immigrants from the population in the Atlantic Ocean (Lepiksaar 1986).

The "migration hypothesis" stipulates that harp seals bred in a few rookeries situated in the low Arctic as today, but were attracted to the Baltic Sea by the high 
organic productivity during its more saline Litorina Sea stage. The high organic productivity, in turn, was a consequence of the higher salinity and warm climate in the late Atlantic and Subboreal periods, combined with increased nutrient levels following flooding by large fluctuations in ocean sea levels at the time (Lepiksaar 1986, Andrén 1999). This hypothesis is also supported by the claimed absence of newborn harp seals in archeological refuse faunas in the Baltic region (Salmi 1963; Lepiksaar 1964; Ekman 1974; Lepiksaar 1986; Lõugas 1997a, 1998).

The "breeding population hypothesis" is supported by the observation that although modern harp seals are migratory and low numbers may reach the Norwegian and Danish coasts during migration, no modern record exists from the Baltic Sea (Winge 1904, Lepiksaar 1986, Wiig 1988). Thus, the great abundance of archeological harp seal remains, in itself, indicates the presence of a permanent breeding population (Sergeant 1991).

Osteometry provides another line of evidence. It has long been claimed that Subboreal harp seals were smaller than their recent relatives (Holmqvist 1912, Lepiksaar 1964). This observation, although never convincingly supported by a large amount of data, has been taken as evidence that the Baltic harp seals were genetically isolated (Ekman 1922). However, the similar size of Subboreal harp seals from the Swedish West coast and the Baltic, has led others to question the "breeding population hypothesis" (Ekman 1974). It was assumed that the harp seals at the Swedish west coast belonged to the population in the Atlantic Ocean, and thus this population must have been smaller than today. By referring to Salmi's (1963) hypothesis that the pack ice areas in the Atlantic Ocean, and thus the breeding grounds for harp seals, were shifted to the south due to the cold continental winters in the Subboreal period, Lepiksaar (1964) offered an explanation of this postulated general decrease in harp seal body size. The ecological rule of Bergmann predicts that evolution favors a large body size in endothermic animals in a cold environment, due to the lower heat loss in these individuals. The harp seals in general, and especially those that undertook southwards migrations in the summer, were in the Subboreal exposed to an unusually warm climate for a long period of the year. As a large body size is costly for the individual to reach, and to maintain, the mean body size of the population gradually decreased when a large body was no longer critical.

Despite the considerable attention paid to the small body size of the harp seal in the Subboreal Baltic Sea, no in-depth osteometric study of the temporal size variation in the harp seal has been published in support of this. This is explained, partly, by the general difficulty of identifying bones of different seal species, especially of young individuals. Also, standardized definitions of seal bone measurements have not been available until recently (Ericson and Storå 1999), making comparisons of results obtained by different researchers difficult.

Herein, we use osteometric data to shed light on the history of the harp seal in the Baltic Sea. To achieve this, we provide criteria for the morphological identification of harp seal humeri and femora, and describe the temporal size variation in adult harp seals. Osteometric data are also used to investigate possible seasonal migrations of harp seals in the Baltic region.

\section{MeTHODS}

Most of the studied archeological samples are from the Subboreal period (3800500 cal B.C.) and situated in the Baltic proper, by which is meant the waters from 
the Aland Sea to the Danish Sounds. We also refer to the Baltic Sea as including both the Baltic proper and the Gulf of Bothnia. One sample is from the Subboreal, but located on the west coast of Sweden. Six samples from Denmark are slightly older dating to the Mesolithic Stone Age, i.e., the Atlantic period.

We chose to use the humerus and the femur for osteometric comparisons, as these bones are numerous in the archeological samples of seal bones. Furthermore, both bones are sufficiently reliable for morphological, species-level identifications in seals.

Metric data of 235 humeri and 175 femora of harp seals from 25 archeological sites were used in the study (Table 1, Fig. 1). Nineteen of the archeological sites date to approximately 3500-1800 cal B.C., i.e., a time interval that falls within the Subboreal period. The largest data sets originate from the Pitted Ware Culture sites of Jettböle on Åland, Ajvide on Gotland, and the Comb Ceramic Culture site Naakamäe on Saaremaa. Comparative studies are presented from Danish Ertebølle sites, Pitted Ware Culture sites on Åland, in Eastern Middle Sweden, along the Swedish west coast, on Gotland, and the Neolithic site of Rzucewo in Poland.

The studied archeological materials are stored in the Museum of National Antiquities in Stockholm, Museum of Aland in Mariehamn, Gothenburg Museum of Natural History, Archaeological Museum in Gdansk, Historical Institute in Tallinn, and the Zoological Museum of the University of Copenhagen.

The archeological samples were compared with data obtained from 107 recent harp seals mostly belonging to the White Sea population (Table 2). Some of the modern seals belong to the Newfoundland population. We used metric data of 24 humeri from adult seals and 83 femora from subadults. Most measurements were taken by JS. Exceptions are those for recent seals stored in the Zoological Museum of the University of Bergen, which were measured by Pirjo Lahtiperä.

ANOVA was used to study the geographic and temporal variation in the skeletal size of harp seals. Significance of pairwise differences was tested using the Scheffé post boc test.

\section{Species Identification Based on the Humerus and the Femur}

It was necessary to discriminate the bones of the harp seals from those of other seal species occurring in the Baltic Sea at the time. Several morphological features useful in this respect have previously been described by Johannes Lepiksaar (unpublished) from whom the terminology also has been adopted. The figures depict individual bones that exhibit the typical condition for each species. As considerable morphological intraspecific variation exists in each of the species, it may not be safe to rely on only a single feature when applying these criteria.

\section{Humerus}

The proximal end of the humerus from the harp seal shows some unique features, which separates this species from ringed seal, gray seal, and harbor seal (Fig. 2). In the harp seal tuberculum lateralis (A) is not divided as in the other species. Because of this, the margin of the crista deltoidea-tuberculum lateralis in the harp seal has a more rounded appearance than in the other species. In the harp seal the tuberculum medialis (B) does not project over the caput as far as in the ringed seal and gray seal. The 
Table 1. Archeological samples of seal bones included in the present study. Abbreviations: Mesol. = Mesolithic; $\mathrm{MN} \mathrm{A}=$ Middle Neolithic A; MN B $=$ Middle Neolithic B; and, LN = Late Neolithic.

\begin{tabular}{|c|c|c|c|c|}
\hline $\begin{array}{l}\text { Geographic } \\
\text { area }\end{array}$ & Site & Chronozone & $\begin{array}{l}\text { Archaelogical } \\
\text { period }\end{array}$ & Reference \\
\hline \multirow[t]{7}{*}{ Gotland } & $\begin{array}{l}\text { Ajvide } \\
\text { D-upper }\end{array}$ & Subboreal & MN A & $\begin{array}{l}\text { Burenhult 1997, } \\
\text { Lindqvist and Possnert } \\
\text { 1997, Storå } 2002\end{array}$ \\
\hline & $\begin{array}{l}\text { Ajvide } \\
\text { D- lower }\end{array}$ & Subboreal & $\mathrm{MN} \mathrm{B} / \mathrm{LN}$ & $\begin{array}{l}\text { Burenhult 1997, } \\
\text { Lindqvist and Possnert } \\
\text { 1997, Storå } 2002\end{array}$ \\
\hline & Ire & Subboreal & $\mathrm{MN} A$ & $\begin{array}{l}\text { Janzon } 1974 \\
\quad \text { Ekman } 1974\end{array}$ \\
\hline & Visby & Subboreal & MN A & $\begin{array}{l}\text { Holmqvist 1912, } \\
\text { Nihlén } 1927\end{array}$ \\
\hline & Västerbjers & Subboreal & $\mathrm{MN} B / \mathrm{LN}$ & Stenberger et al. 1943 \\
\hline & Hemmor & Subboreal & $\mathrm{MN}$ A & $\begin{array}{l}\text { Wallin and } \\
\text { Martinsson-Wallin } 1996\end{array}$ \\
\hline & Hau & Subboreal & ? & Österholm 1992 \\
\hline \multirow[t]{5}{*}{ Åland } & Jettböle & Subboreal & MN A & $\begin{array}{l}\text { Winge, unpublished; } \\
\text { Storå } 2000\end{array}$ \\
\hline & Härdalen & Subboreal & MN A & Storå 2000 \\
\hline & Jettböle & Subboreal & $\mathrm{MN} B / \mathrm{LN}$ & Storå 2000 \\
\hline & Kö̈llsveden & Subboreal & $\mathrm{MN} B / \mathrm{LN}$ & Storå 2000 \\
\hline & Ásgårda & Subboreal & $\mathrm{MN} \mathrm{B/LN}$ & Storå 2000 \\
\hline \multirow{3}{*}{$\begin{array}{l}\text { Eastern } \\
\text { Middle } \\
\text { Sweden }\end{array}$} & Brunn & Subboreal & MN A & Schnell 1930 \\
\hline & Korsnäs & Subboreal & $\mathrm{MN} A$ & $\begin{array}{r}\text { Aaris-Sørensen 1978, } \\
\text { Olsson et al. } 1994\end{array}$ \\
\hline & Åloppe & Subboreal & $\mathrm{MN} A$ & $\begin{array}{l}\text { Almgren 1906, } \\
\text { Lindqvist } 1916\end{array}$ \\
\hline $\begin{array}{l}\text { Swedish } \\
\text { West } \\
\text { Coast }\end{array}$ & Rörvik & Subboreal & $\mathrm{MN} A$ & Henrici 1936 \\
\hline \multirow[t]{2}{*}{ Estonia } & Naakamäe & Subboreal & MN B & Lõugas $1997 a, b ; 1998$ \\
\hline & Loona & Subboreal & MN B & Lõugas $1997 a, b ; 1998$ \\
\hline Poland & Rzucewo & Subboreal & MN A & $\begin{array}{l}\text { Król } 1997, \\
\text { Lasota-Moskalewska 1997, } \\
\text { Lubicz-Niezabitowski } 1928\end{array}$ \\
\hline \multirow{6}{*}{$\begin{array}{l}\text { Denmark- } \\
\text { Mesolithic } \\
\text { sites }\end{array}$} & Ertebølle & Atlantic & Mesol. & $\begin{array}{l}\text { Madsen et al. 1900, } \\
\quad \text { Møhl } 1970\end{array}$ \\
\hline & Sølager & Atlantic & Mesol. & Møhl 1970 \\
\hline & Mejlgaard & Atlantic & Mesol. & Møhl 1970 \\
\hline & Ølby Lyng & Atlantic & Mesol. & Møhl 1970, 1971 \\
\hline & $\emptyset_{\text {stenkær }}$ & Atlantic & Mesol. & Andersen 1992 \\
\hline & $\begin{array}{l}\text { Grisby, } \\
\quad \text { Bornholm }\end{array}$ & Atlantic & Mesol. & $\begin{array}{l}\text { Møhl, unpublished; } \\
\text { Storå, personal observation }\end{array}$ \\
\hline
\end{tabular}




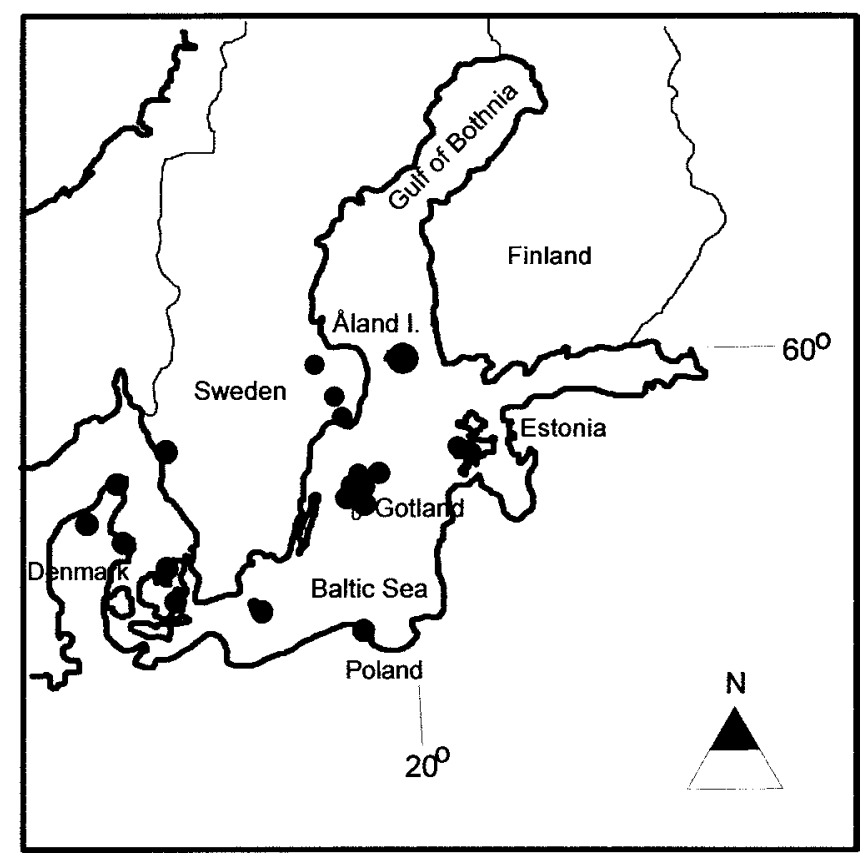

Figure 1. Map of the Baltic Sea, i.e., the Baltic proper and the Gulf of Bothnia. The geographic locations of the archaeological sites are indicated.

tuberculum medialis in the harbor seal resembles that in the harp seal, but the tuberculum lateralis in the former is similar to ringed seal and gray seal.

Distally, the facies articularis (C) in the harp seal does not continue as far up towards the diaphysis as in the other species. In the harp seal the medial part of facies articularis does not continue "over" the epicondylus medialis. The general morphology of facies articularis for the harbor seal resembles to some extent that of the harp seal, but the medial part is similar to gray seal and ringed seal. Generally, on the cranial side of the distal diaphysis (D), the medial margin forms a sharper ridge (above condylus medialis) in the harp seal in comparison with the other species in which the margin is smoother and more rounded. The difference is discernible also in the cross-section of the diaphysis, which in the harp seal has a sharper border between the cranial and medial sides of the diaphysis (E). In the harp seal the Crista epicondylus lateralis does not project as far laterally as in the other species (F). In cross-section the caudal side of the midpart of the diaphysis in the harp seal may have an almost flat, or sometimes even slightly concave outline $(G)$, while it is more convex and rounded in the other species.

In general, the midpart of the diaphysis in the harp seal is more robust and has a "wider" appearance than in the other seal species $(\mathrm{H})$, which, together with the above mentioned morphological differences (D, F), can be used in the identification of humeri for which the epiphyses have not fused to the diaphysis. Also, the crosssection of the open distal metaphysis of diaphysis from the harp seal normally appears to be more rectangular than in the other species. This is mostly due to the contour of the medial margin, which in the harp seal is oriented more closely in a cranial-caudal direction than in the other species $(\mathrm{J})$. 
Table 2. Number of studied individuals of recent harp seals, divided into age classes. The majority of seals belong to the White Sea population. Acronyms: NRM = Swedish Museum of Natural History; ZMCU = Zoological Museum, University of Copenhagen; and, $\mathrm{ZMB}=$ Zoological Museum University of Bergen.

\begin{tabular}{lcccccr}
\hline \hline Depository & Fetus & $\begin{array}{c}\text { Yearling } \\
(0-3 \mathrm{mo})\end{array}$ & $\begin{array}{c}\text { Yearling } \\
(10-11 \mathrm{mo})\end{array}$ & $\begin{array}{c}\text { Yearling, } \\
\text { or subadult }\end{array}$ & Subadult & Adult \\
\hline NRM & & & 59 & 9 & 6 & 19 \\
ZMCU & 1 & 4 & & 2 & 2 & 5 \\
ZMB & & 4 & & & \\
\hline
\end{tabular}

\section{Femur}

The general morphology of the diaphysis is useful for distinguishing harp seal femora from those of the other species (Fig. 3). In the harp seal the midpart of the diaphysis is relatively wide (A) and in lateral (and medial) view almost straight in outline (B). In the ringed seal the midpart is relatively narrower, and in lateral view the diaphysis is bowed. These criteria are useful for identifying bones from subadult seals also. In young gray seals the diaphysis may have a straight appearance (in a lateral view), but normally the size of the caput is markedly larger, in proportion to the overall size of the bone. Also, in the harbor seal, the diaphysis may appear straight in lateral view, but the midpart is generally narrower than in the harp seal. In unfused femora the outline of fossa trochanterica in the harp seal is often wider than in the ringed seal $(\mathrm{C})$.

\section{Ageing Harp Seal Humeri and Femora}

Based on size and epiphyseal fusion status (according to the results of Storå 2001), the archaeological humeri and femora have been classified as being from either adult individuals or subadult individuals. For the humerus, bones that have the proximal epiphysis unfused, and the distal epiphysis either fused or unfused, were classified as subadult. For the femur, bones with the distal epiphysis unfused, but the proximal fused or unfused, were classified as subadult. Bones with the epiphyses fusing or completely fused were regarded as adults. In a number of archaeological bones, the damaged ends prevented an examination of their epiphyseal status, but they could still be allocated to either age group based on size. Most often this concerned on the one hand the smallest subadult bones, and on the other the largest adult bones.

The recent seals have been aged both on the criteria for humeri and femora described above, and on counts of dental annuli that were available for ten individuals (see Storå 2001) (Table 2).

\section{Measurements}

Measurements obtained from the humerus and the femur are illustrated in Figure 4. The humerus was used in the analysis of the temporal size variation in adult harp seals because this bone is suitable for age determinations, frequently occurs in the archaeological samples, and the diaphyseal part of the humerus is often recovered.

The sample sizes increased considerably by using diaphyseal measurements compared to measuring complete bones only. However, a drawback of measuring the 
Phoca groenlandica
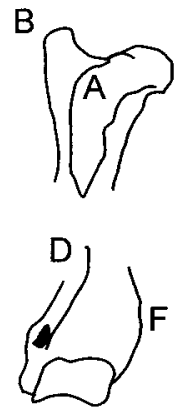

cranial view
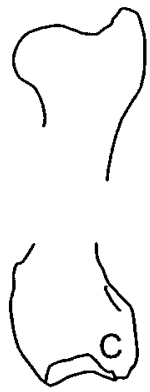

caudal view
Phoca hispida
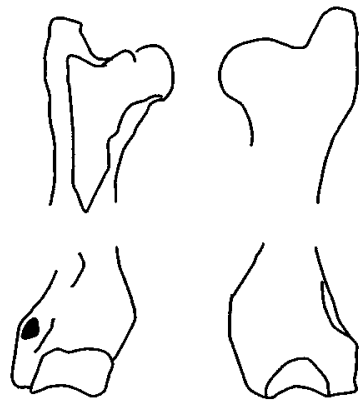

cranial view caudal view

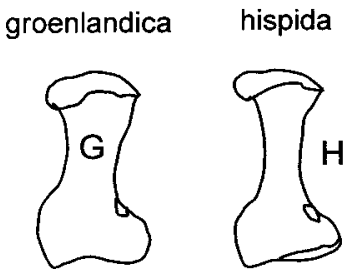

caudal view

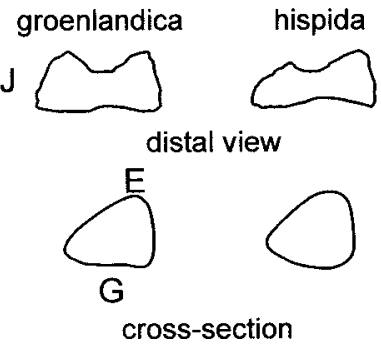

Figure 2. Morphological criteria (A-J) for the species identification of seal humeri. See text for explanation.

smallest height of the diaphysis is the rather high interobserver variation (Ericson and Stora 1999). As the subadult individuals in this study were measured by more than one person, we chose instead to use the femur in the analysis of the age structure of the subadult harp seals. The diaphyseal measurements of the femur are considerably more reliably scored than those of the humerus, which outweighs the fact that femora are less frequently found in archaeological deposits than are humeri. Measurement definitions and abbreviations follow Ericson and Storå (1999).

\section{RESULTS}

\section{Size of Adult Harp Seals in the Atlantic and Subboreal Periods}

A considerable variation in the size of the harp seals in the Baltic region was observed among samples from different time periods. The differences in size (expressed by the diaphyseal height of the humerus--the most frequently observed measurement) is highly significant (Table $4, F_{2,256}=84.97, P<0.000$ ). The large variation can be chiefly ascribed to the much smaller size of the Subboreal seals compared to the Atlantic and recent harp seals. The mean diaphyseal height in the sample of Subboreal seals differs significantly $(P<0.000)$ from both Atlantic and Recent seals, while those observed in Atlantic harp seals of Denmark and modern 


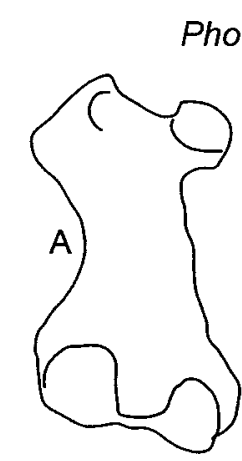

caudal view

C

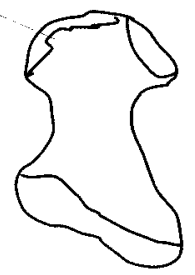

Phoca groenlandica

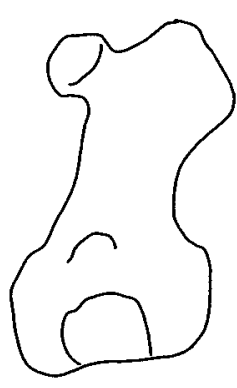

cranial view

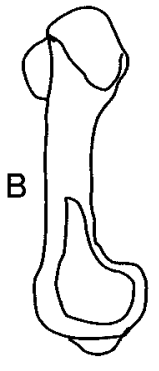

lateral view
Phoca hispida

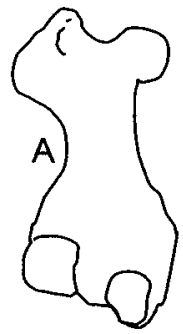

caudal view

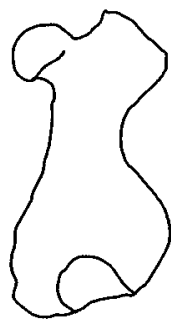

cranial view

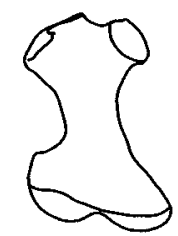

Figure 3. Morphological criteria (A-C) for the species identification of seal femora. See text for explanation.

seals do not differ significantly $(P=0.46)$. No geographic variation could be detected among Subboreal harp seals in the Baltic and on the Swedish west coast $\left(F_{5,222}=2.09, P=0.15\right)$.

Besides the large difference in size observed between the Atlantic and Subboreal populations of harp seals, there was also a tendency towards a decrease in size during the Subboreal. This trend is statistically significant $\left(F_{1,77}=6.47, P=0.01\right)$ when comparing the mean sizes of older (MN A) and younger (MN B) Subboreal sites situated in the same geographic region (Aland). A similar decrease in size from older to younger sites also occurs between the pooled samples of all Baltic sites, but was not statistically significant $\left(F_{1,221}=3.64, P=0.06\right)$.

\section{Age Structure of the Baltic Harp Seals}

The femora of subadult harp seals recovered at archaeological sites in the Baltic exhibit a considerable size variation (Fig. 5A). Several archaeological femora are smaller than the recent sample (Fig. 5B), and it is reasonable to assume that this cluster consists of individuals that are newborn, or a few weeks old. Although the sample of 0- to 3-mo-old recent harp seals is small, these individuals fall well into the cluster of the smallest archaeological individuals. Furthermore, one femur found at the late Middle Neolithic (MN B, Subboreal) site Åsgårda on Åland, is considerably smaller than the recent sample. This bone is smaller than in newborn recent harp seals, but larger than a fetus obtained from a female that died in late November to early December.

The comparison of femur measurements of archaeological and recent harp seals indicates that young, most likely newborn, harp seals were common in the Baltic in 
Table 3. Age classes of harp seal humeri in the archaeological samples.

\begin{tabular}{llrrrr}
\hline \hline \multirow{2}{*}{ Geographical area } & \multicolumn{1}{c}{ Site } & Subadults & Adults & $\begin{array}{c}\text { Unknown } \\
\text { age }\end{array}$ & Total \\
\hline Gotland & Ajvide D-upper & 108 & 24 & 19 & 151 \\
& Ajvide D-lower & 8 & 1 & 1 & 10 \\
& Ire & 21 & 6 & 16 & 43 \\
& Visby & 5 & 7 & 1 & 13 \\
& Västerbjers & 3 & 1 & & 4 \\
& Hemmor & 11 & 4 & & 15 \\
& Hau & 10 & 5 & 2 & 17 \\
Áland & Jettböle I & 82 & 46 & 36 & 164 \\
& Härdalen & 4 & 4 & & 8 \\
& Jettböle II & 1 & 3 & 5 & 9 \\
& Källsveden & 3 & 4 & & 7 \\
Eastern Middle Sweden & Asgårda & 5 & 20 & 2 & 27 \\
& Brunn & 10 & 21 & 34 & 65 \\
& Korsnäs & 12 & 11 & 8 & 31 \\
Swedish West Coast & Aloppe & 1 & & 2 & 3 \\
Estonia & Rörvik & 6 & 4 & 1 & 11 \\
& Naakamäe & 140 & 50 & 20 & 210 \\
Poland & Loona & 12 & 4 & 1 & 17 \\
Denmark—Mesolithic & Rzucewo & 8 & 7 & & 15 \\
& Ertebølle & 1 & & & 1 \\
& Sølager & & 1 & 1 & 2 \\
& Mejlgaard & & 1 & & 1 \\
& Ølby Lyng & 1 & 2 & 2 & 5 \\
& Østenkær & & 2 & 1 & 3 \\
& Grisby, Bornholm & 3 & & & 3 \\
\hline & & & & &
\end{tabular}

the Subboreal. Also, no distinct size groupings were observed in the sample taken as a whole, which indicates that subadult harp seals of all age classes occurred in the Baltic. Thus, indicating that harp seals were present in the Baltic throughout the year.

The largest archaeological subadult femora, which have the proximal epiphysis fusing or fused, are slightly smaller than the modern ones (Fig. 5A, B). This indicates that subadult harp seals in the Baltic did not reach body sizes comparable to modern harp seals. In modern seals the process of fusion in the proximal end of femur starts at approximately 2-4 yr of age (Storå 2001).

\section{Geographic and Temporal Variation in the Age Structure of the Hunted Harp Seals}

Although harp seals of all ages seemingly occurred in the Baltic, there is a distinct geographic pattern in the occurrence of the youngest individuals. Bones deriving from presumably newborn individuals have been found only at sites in Eastern Middle Sweden, Gotland, and Aland, while no femora recovered at an archaeological site in Estonia have a diaphysis shorter than $44 \mathrm{~mm}$ (Fig. 5A). Also at Västerbjers, a site situated on the eastern coast of Gotland (Fig. 1), the youngest harp seals are unrepresented. 


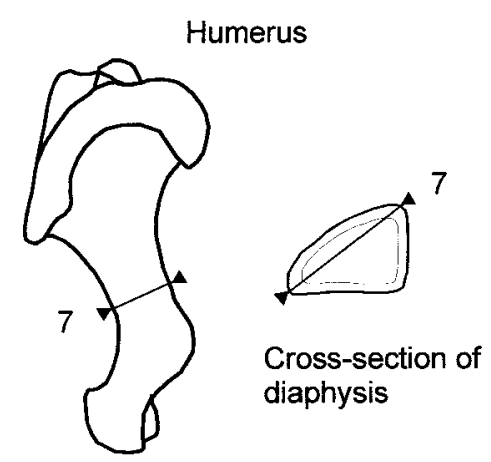

Lateral view

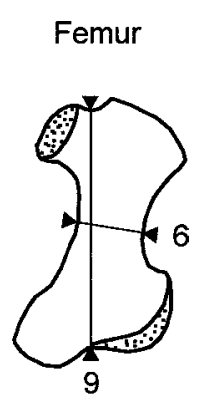

Cranial view

Figure 4. Definition of measurements (modified from Ericson and Storå 1999). 7: smallest height of the humeral diaphysis; 9: smallest length of the femoral corpus; and 6: smallest breadth of the femoral diaphysis.

There is a considerable variability in the proportions of adult and subadult harp seals deposited at archaeological sites in different parts of the Baltic. Based on ageclass determinations of humeri, the proportion of adult harp seals averages $55 \%-$ 60\% at sites in Aland and Eastern Middle Sweden, while only ca. 25\% of the bones are of adults at sites in Gotland and Estonia. The intra-area variation in the proportion of adults is small in all areas except Eastern Middle Sweden (from which only two sites are included in the study), and the pattern observed seems to be robust.

\section{DisCUSSION}

\section{The Subboreal Harp Seal Population in the Baltic Region}

Archaeological finds in Denmark show that the low Arctic harp seal occurred regularly in the North Sea area during the late Atlantic. Osteometric data indicate that these individuals reached the same adult size as extant harp seals of the northeastern Atlantic Ocean populations (Table 4). This, together with the paucity of late Atlantic finds of harp seals in the Baltic Sea (Ericson 1989), suggests that these individuals belonged to the Atlantic Ocean population. Today, harp seals from breeding grounds in the northeastern Atlantic annually undertake long-distance migrations outside the breeding season. Although the harp seals occurred in Danish waters in the Atlantic period, they obviously did not often reach far into the Baltic Sea (Ericson 1989).

In the following Subboreal period, harp seals occurred all over the Baltic, as far north as the northern Gulf of Bothnia (Lepiksaar 1975, Forstén and Alhonen 1977). The osteometric analysis shows that these harp seals were smaller as adults compared to their extant conspecifics. This stands in contrast to the harp seals recovered from the earlier, Atlantic period sites, which are equal in size to modern harp seals. The decrease in adult size from the Atlantic period to the Subboreal period, could in theory have affected the entire northeast Atlantic Ocean population, but this is contradicted by archaeological finds in northern Norway. Harp 
Table 4. Descriptive statistics for the height of humeral diaphyses in samples of adult harp seals from the Stone Age and recent time.

\begin{tabular}{lrcccc}
\hline \hline & \multicolumn{1}{c}{$n$} & Mean & Min. & Max. & SD \\
\hline Recent sample & 24 & 28.2 & 24.8 & 33.4 & 2.22 \\
Atlantic period, Denmark & 7 & 27.2 & 23.3 & 28.6 & 1.87 \\
Subboreal period, all sites $^{\mathrm{a}}$ & 228 & 23.5 & 18.6 & 28.0 & 1.76 \\
$\quad$ Subboreal, MN A (older) & 137 & 23.7 & 19.6 & 28.0 & 1.70 \\
Subboreal, MN B (younger) & 86 & 23.2 & 18.6 & 27.7 & 1.84 \\
Subboreal, West Swedish coast & 5 & 22.0 & 20.1 & 24.0 & 1.45 \\
Subboreal, Baltic, all sites & 223 & 23.5 & 18.6 & 28.0 & 1.76 \\
Subboreal, Alland, all sites & 79 & 23.1 & 18.6 & 28.0 & 2.03 \\
$\quad$ Subboreal, Åland, MN A (older) & 50 & 23.6 & 19.9 & 28.0 & 1.98 \\
$\quad$ Subboreal, Alland, MN B (younger) & 29 & 22.4 & 18.6 & 26.2 & 1.95 \\
Subboreal, Gotland & 48 & 23.7 & 19.6 & 28.0 & 1.72 \\
Subboreal, eastern middle Sweden & 34 & 23.9 & 21.9 & 25.7 & 1.05 \\
Subboreal, Estonia & 55 & 23.6 & 19.1 & 27.7 & 1.68 \\
Subboreal, Poland & 7 & 23.7 & 21.7 & 26.0 & 1.44 \\
\hline a Includes five humeri from the Gotlandic site Hau which cannot be designated to MN A \\
or MN B.
\end{tabular}

seal remains recovered at Subboreal sites in Varangerfjord agree in size with the extant population (see data in Hodgetts 1999, 2001).

The decrease in adult size may thus be a phenomenon restricted to the Baltic region. However, harp seals found at Subboreal sites on the west coast of Sweden are also of this smaller size (Table 4). Ekman (1974) compared the size of the harp seals from the Gotlandic sites Ire, Gullrum and Visby, with those from Rörvik, a Pitted Ware Culture site on the west coast of Sweden. As no size differences were found between the Gotlandic and the west coast harp seals, he concluded that Holmqvist's (1912) interpretation of an isolated, permanent population of harp seals in the Baltic could not be supported. However, it was presumed that harp seals recovered at Rörvik belong to the Atlantic Ocean population, but this may not be the case. The difference in adult size between Subboreal harp seals from the Baltic Sea and the Swedish west coast on one hand, and individuals from the northeastern Atlantic Ocean (both extant and prehistoric) on the other, suggests a limited gene-flow between these populations (contra Ylimaunu 2000). Judging from the large number of archaeological finds, presumably the Baltic proper constituted the centre of distribution of the south Scandinavian harp seal population in the Subboreal period. The harp seals hunted in the Kattegat area at this time may then be individuals belonging to a population that bred in the Baltic Sea and undertook migrations to areas west of Öresund and Store Bælt.

\section{Indications of A Local Breeding Colony, and its Location}

As indicated by the lack of clusters into size classes when the samples of unfused femora from all geographic areas are lumped together (Fig. 5), harp seal of many ages lived in the Baltic Sea during the Subboreal period. Also, newborn individuals are represented in the archaeological sample as judged from their small size. These femora compare to the size of newborn, or almost newborn, harp seals in the recent 


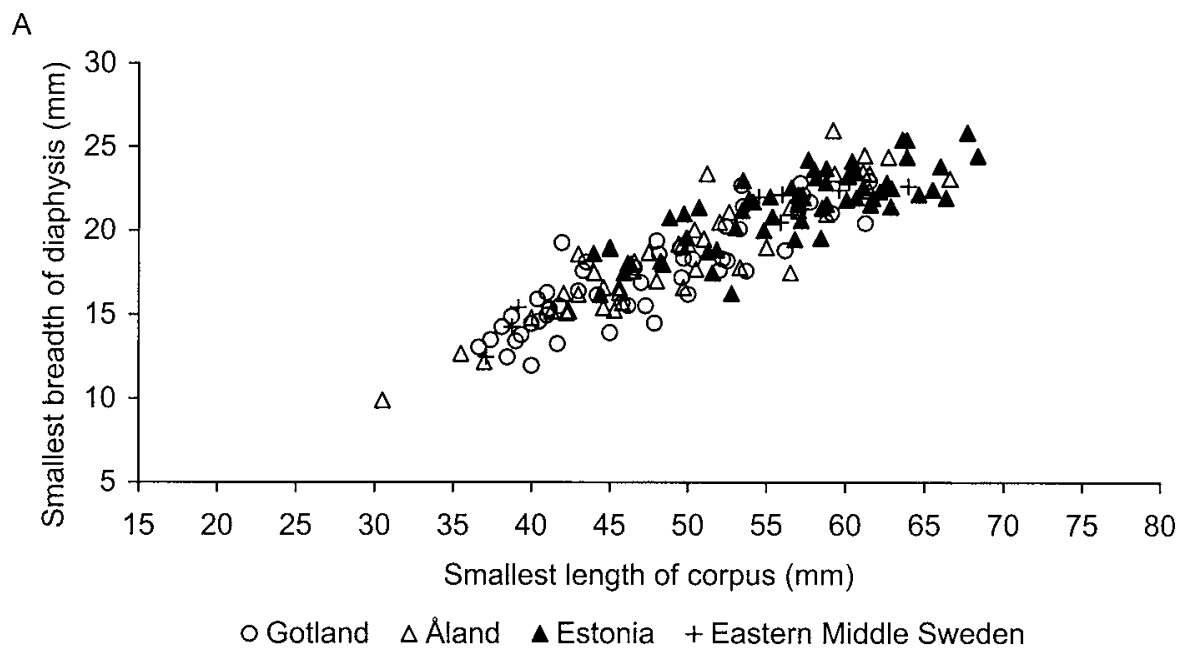

$\mathrm{B}$

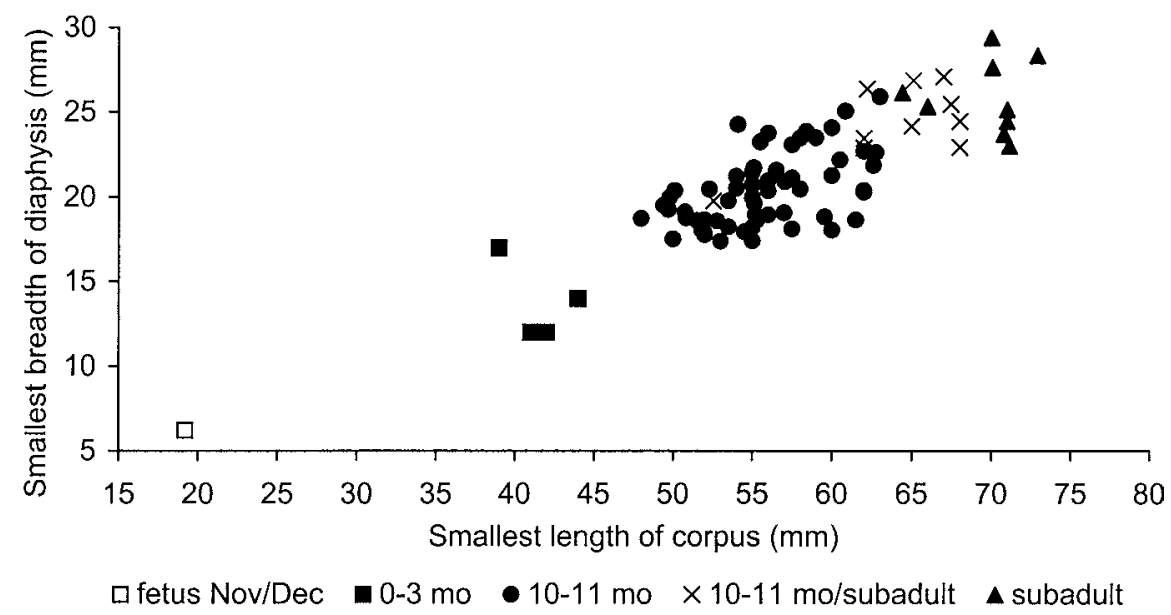

Figure 5. Measurements of subadult harp seal femora obtained from (A) archaeological sites in the Baltic region (divided into geographic areas), and (B) the extant north Atlantic Ocean population. The extant subadult seals are between 2 and 4 yr old (Storå 2001).

sample. However, the conversion of bone size of archaeological specimens into individual age calculated from a sample of recent harp seals, relies on the assumptions that the pups in both populations are of the same size at birth, and that the growth curves are approximately similar for the age interval compared.

Whether the prehistoric harp seals were of the same size at birth as their extant relatives, is difficult to test. The overall similarity of the Figures $5 \mathrm{~A}$ and $5 \mathrm{~B}$, where the smallest (probably newborn) individuals are of a similar size, suggests no major differences between the populations. We conclude that a local harp seal rookery existed in the Baltic region during the Subboreal period. Although it remains to 
be verified, it seems reasonable to assume that the prehistoric Baltic harp seal population had only a single breeding ground in the region. Some have questioned whether the ice conditions in the Baltic Sea in the Subboreal permitted the harp seal to breed on pack ice (Winge 1904; Pira 1926; Degerbøl 1933; Møhl 1970; Aaris-Sørensen 1988; Lõugas 1997a, 1998). However, the ice conditions in the Litorina Sea were probably more severe than in the Baltic Sea today, at least during the earliest Subboreal (Salmi 1963), suggesting that extensive pack ice areas may have existed in the area. It has also been suggested that a harp seal breeding ground could have been located in the Gulf of Bothnia (Ylimaunu 2000).

As the newborn harp seal does not enter the water before it has moulted the white fur about three weeks after birth, several of the small bones at these sites derive from pups killed at the breeding ground by hunters from sites situated in eastern middle Sweden and on Aland and Gotland. The considerable geographic bias of the archaeological sites studied herein precludes a final statement about the location of the breeding ground, but it seemingly was located south of Åland, between mainland Sweden and Gotland.

Temporal variation in the location of the breeding ground is suggested by the distribution of the youngest harp seal pups. The Gotlandic sites dated to the older Middle Neolithic period ( $\mathrm{MN} \mathrm{A}$ ) all have remains of these young pups, while such remains are lacking on the only younger ( $\mathrm{MN} \mathrm{B}$ ) site on the west coast of Gotland, Ajvide D-lower. This suggests that the inhabitants at Ajvide could no longer easily access the breeding grounds. The gradually warmer winters in the late Subboreal may have caused a northward shift in their location.

A breeding ground situated somewhere between mainland Sweden and Gotland is consistent with the observed differences in the proportions of adults $v$ s. subadults in the archaeological samples. A general difference exists between the Gotlandic and Estonian sites on one hand, and those in Eastern Middle Sweden and Åland on the other. In the former areas, subadults constitute a much larger proportion among the hunted seals. Despite the similar low proportion of adults, newborn harp seals are found at the Gotlandic, but not the Estonian sites (Fig. 5A). The only Gotlandic site that differs from this pattern is Västerbjers, situated on the eastern coast of the island (Fig. 1), where no newborn harp seals have been found. At both Västerbjers and the Estonian sites, the smallest harp seal bones correspond to those in modern harp seals at about 3 mo of age or older. Seals of this size class are also common west of Gotland, and it seems that herds of young seals dispersed in several directions from the breeding grounds. The similarity in the age proportions between Gotlandic and Estonian sites indicates that they reflect the true age composition of the harp seals in these areas fairly well. Thus, we conclude that the adults did not have the same migration patterns as subadult individuals. The adults less often migrated into the waters east of Gotland.

\section{Why Did the Population Go Extinct?}

The Baltic population of harp seals was large enough to constitute a rewarding prey during the Stone Age. Judged from the archaeological record, the population was at its largest in the Middle Neolithic, after which it rapidly declined. The small number of harp seal remains in archaeological refuse faunas after the Stone Age, could be a consequence of shifting patterns in the human exploitation of the natural resources. On the other hand, seals were common as prey also after the Neolithic. 
The disappearance of the harp seal from the Baltic region, and the cause of this has been much discussed. Bearing on this issue is the small adult size of the Baltic harp seals in comparison with their contemporary and recent conspecifics in the north Atlantic Ocean. To this can now be added the observed tendency towards a decreasing size of adult harp seals in the Baltic. The smaller size of Baltic harp seals has been explained by an adaptation to the warmer climate in the Subboreal, as predicted by Bergmann's ecological rule (Lepiksaar 1964), or by genetic drift in the Baltic population following a geographic, and consequently genetic, isolation from the north Atlantic Ocean harp seals (Ekman 1922, Forstén and Alhonen 1975, Sergeant 1991).

Other proposed explanations for the decrease and final disappearance of the harp seals in the Baltic are climatic changes (Holmqvist 1912, Ekman 1922, Pira 1926, Lepiksaar 1986, Lõugas 1998), interspecific competition (Sergeant 1991), and overhunting by humans (Storå 2000, 2002; but see Sergeant 1991). Any of these factors, which are all likely to have occurred, may have been disastrous when combined with a low genetic diversity in the Baltic harp seal population.

Harp seals were extensively hunted by Stone Age Man, and bone harpoons have been found associated with complete skeletons of seals that have escaped the hunters only to die and sink to the sea floor soon after (Leppäaho et al. 1936, Cederschiöld 1959, Salmi 1963). The analyses of the age composition in the refuse faunas indicate that a substantial killing of yearlings occurred at all sites (also see Storå $2000,2002)$. The harp seals are rather solitary during their first year of life, but these yearlings may form migrating groups that are more or less independent from the herds of adult animals (Sergeant 1991). The migrating yearlings obviously suffered from an extensive hunting by Stone Age Man, and the number of subadults in the population was greatly reduced.

McLean (1986, 1988, 1991) has formulated an interesting hypothesis bearing on both the dwarfing and the local extinction of the Baltic harp seal. He postulates that in a climate that is warmer than the optimal, mammalian fertility is reduced because the female body shunts blood to the peripheral part of the body for cooling. This, in turn, reduces the uterine blood flow to the embryo, resulting in a decreased supply of, e.g., oxygen, water, nutrients, and hormones (McLean 1991). Also, the cooling of the embryo decreases. In domestic mammals heat-induced death of embryos occurs in large numbers on a global scale, and it also accounts for dwarfing and skeletal abnormalities (McLean 1991). The principle is the same for all wild animals, however, and has been used to explain the global extinction of land mammals at the end of the last glacial. However, we are unaware of studies of the interrelationship between climate and female fertility in marine mammals.

The mean temperatures in the Baltic region are known to have oscillated also during generally warm periods in the Atlantic and Subboreal. It is possible that the harp seal established its Baltic population in a colder phase when the polar front had moved south. The gradual warming up, and the decreasing fertility following from the reproductive physiological principles outlined above, could then have become one more negative factor that eventually led to the local extinction of the harp seal in the Baltic.

\section{ACKNOWLEDGMENTS}

Lisa Hodgetts shared unpublished data on archaeological harp seals in Norway, Pirjo Lahtiperä measured specimens in her care at the Zoological Museum of Bergen University, 
and Anders Bignert discussed statistical methods. The Zoological Museum of Bergen University, Zoological Museum of the University of Copenhagen and Swedish Museum of Natural History kindly put specimens of recent harp seals at our disposal. Archaeological samples were studied in the collections of the Museum of National Antiquities, Museum of Aland, Gothenburg Museum of Natural History, Archaeological Museum in Gdansk, and Historical Institute in Tallinn. Gregory Mayer and an anonymous reviewer provided valuable comments on an earlier version of the manuscript. All this is gratefully acknowledged.

\section{Literature Cited}

Aaris-Sørensen, K. 1978. Knoglematerialet fra den mellemneolitiske boplads ved Korsnäs. Riksantikvarieämbetet och Statens Historiska Museer Rapport 1978:8.

Aaris-Sørensen, K. 1988. Danmarks forhistoriske dyreverden. Gyldendal, Denmark.

Almgren, O. 1906. Uppländska stenåldersboplatser. Fornvännen 1:1-19.

Andersen, S. H. 1992. Marin udnyttelse af Limfjorden i Stenalderen. Limfjordsfiskeri i fortid och nutid. Limfjordsprojektet Rapport 4:65-96.

Andersen, S. H. 1995. Coastal adaptation and marine exploitation in Late Mesolithic Denmark - with special emphasis on the Limfjord region. Pages 41-66 in A. Fischer, ed. Man and sea in the Mesolithic: Coastal settlement above and below present sea levels. Monograph 53. Oxbow Books, Oxford, UK.

ANDRÉn, E. 1999. Holocene environmental changes recorded by diatom stratigraphy in the southern Baltic Sea. Meddelanden från Stockholms universitets institution för geologi och geokemi 302, Stockholm, Sweden.

Boessneck, J., AND A. von DEN Driesch. 1979. Die Tierknochenfunde mit Ausnahme der Fischknochen. Pages 24-421 in J. Boessneck, A. von den Driesch, and L. Stenberger, eds. Eketorp. Befestigung und Siedlung auf Öland/Schweden. Die Fauna. Almqvist and Wiksell International, Stockholm, Sweden.

Burenhult, G. 1997. Säljägare och svinaherdar på Ajvide. Pages 15-21 in G. Burenhult, ed. Ajvide och den moderna arkeologin. Natur och Kultur, Falköping, Sweden.

Cederschiöld, L. 1959. Om två sälharpuner från Hälsinglands stenålder. Fornvännen 54: $36-40$.

Daugnora, L. 2000. Fish and seal osteological data at Šventoji sites. Lietuvos Archeologija 19:85-101.

DegerbøL, M. 1933. Danmarks pattedyr i Fortiden i sammenligning med recente former. Videnskabelige Meddelelser fra Dansk naturhistorisk Forening 96, Reitzels Forlag, Copenhagen, Denmark.

EKMAN, J. 1972. Genomgång av benmaterialet från Hasslingehult. In C. Cullberg. Boplats Hasslingehult Göteborg. FYNDrapporter 1972:571-577.

Ekman, J. 1974. Djurbensmaterialet från stenålderslokalen Ire, Hangvar sn, Gotland. Pages 212-246 in G. O. Janzon, Gotlands mellanneolitiska gravar. Studies in NorthEuropean Archaeology 6. Almqvist and Wiksell, Stockholm, Sweden.

EkMAN, S. 1922. Djurvärldens utbredningshistoria på skandinaviska halvön. Bonniers, Stockholm, Sweden.

Ericson, P. G. P. 1989. Säl och säljakt i Östersjöområdet under stenåldern. Pages 57-64 in E. Iregren and R. Liljekvist, eds. Faunahistoriska studier tillägnade Johannes Lepiksaar. Symposium 26 maj 1988. Report Series 33. Institute of Archaeology, University of Lund, Lund, Sweden.

Ericson, P. G. P., AND J. STORÅ. 1999. A manual for the skeletal measurements of the seal genera Halichoerus and Phoca (Mammalia: Pinnipedia). Department of Vertebrate Zoology, Swedish Museum of Natural History, Stockholm, Sweden. 25 pp. Available at http://www.nrm.se/ve/birds/reprints.html.en

Forstén, A., And P. Alhonen. 1975. The subfossil seals of Finland and their relation to the history of the Baltic Sea. Boreas 4:143-155. 
Forstén, A., AND P. Alhonen. 1977. Additional subfossil seals from Finland. Commentationes Biologicae 84:3-8.

Fredén, C. 1975. Subfossil finds of Arctic whales and seals in Sweden. Sveriges geologiska undersökning ser C710 69:(2). Stockholm, Sweden.

FredÉn, C. 1984. Faunahistoriska notiser om några av Naturhistoriska museets daterade subfossila fynd. Göteborgs Naturhistoriska Museum Årstryck 1984:31-45.

Henrici, P. 1936. Benfynd från boplatsen vid Rörvik. Pages 82-91 in S. Janson. En boplats från yngre stenåldern vid Rörvik i Kville s:n. Göteborgs och Bohusläns fornminnesförenings Tidskrift 1936, Göteborg, Sweden.

Hodgetts, L. M. 1999. Animal bones and human society in the late Younger Stone Age of arctic Norway. Ph.D. thesis, University of Durham, Durham, UK. 394 pp.

HodgetTs, L. M. 2001. Seal exploitation and intra-site variation in the younger Stone Age of Varangerfjord, North Norway. Pages 109-116 in A. Millard, ed. Archaeological Sciences '97. Proceedings of the conference held at the University of Durham 2-4 September 1997. BAR International Series 939.

HolmQvist, O. 1912. Tierknochen aus den steinzeitlichen Wohnplätzen in Visby und Hemmor sowie aus einem Öländischen Ganggrabe. Kungliga Vetenskaps Akademiens Handlingar 49:71-75.

JANZON, G. O. 1974. Gotlands mellanneolitiska gravar. Studies in North-European Archaeology 6. Almqvist and Wiksell, Stockholm, Sweden.

Kinberg, J. G. H. 1869. Om arktiska Phocaceer, funna uti mellersta Sveriges glaciallera. Kungliga Vetenskaps Akademiens Förhandlingar 1869:13-51.

KRóL, D. 1997. Excerpts from Archaeological research at Rzucewo, Puck Region. Pages 135-150 in D. Król. ed. The built environment of coast areas during the Stone Age. The Baltic Sea-Coast Landscapes Seminar Session No. 1. The Archaeological Museum in Gdansk, Gdansk, Poland.

KÖnigsson, E. S., J. LepiKsaAR And L.-K. KÖnigsson. 1971. Stenålderboplatsen i Alby på Öland. Preliminärt meddelande. Fornvännen 66:34-46.

Königsson, L.-K., E. S. Königsson, E. Bendixen and G. Possnert. 1993. Topography and chronology of the Alby Stone Age settlement on southeastern Öland, Sweden. Pages 13-39 in G. Arwidsson et al. eds. Sources and resources. Studies in honour of Birgit Arrhenius. PACT-Journal of the European Network of Scientific and Technical Cooperation for the Cultural Heritage 38 I.2.

Lasota-Moskalewska, A. 1997. Animal remains from the Neolithic settlement at Rzucewo. Pages 162-166 in D. Król, ed. The built environment of coast areas during the Stone Age. The Baltic Sea-coast landscapes seminar, Session No. 1. The Archaeological Museum in Gdansk, Gdansk, Poland.

LepiksaAR, J. 1964. Subfossile Robbenfunde von der schwedischen Westküste. Zeitschrift für Säugetierkunde 29:257-266.

LEPIKSAAR, J. 1974. Djurrester från den mellanneolitiska (gropkeramiska) boplatsen vid Äs, Romfartuna socken, Västmanland. Pages 140-156 in L. Löfstrand. Yngre stenålderns kustboplatser. Aun 1. Uppsala, Sweden.

LEPIKSAAR, J. 1975. The analysis of the animal bones from the Bjurselet settlement, Västerbotten, northern Sweden. Skytteanska Samfundets Handlingar 8. Umeå, Sweden.

LEPIKSAAR, J. 1986. The Holocene history of the theriofauna in Fennoscandia and Baltic countries. Striae 24:51-70.

Lepiksaar, J. Unpublished. Osteologia III. Phocidae. Unpublished manuscript at the Archaeoosteological Research Laboratory. Royal Castle of Ulriksdal, SE-17079 Solna, Sweden.

Leppäaho, J., M. Sauramo and V. Korvenkontio. 1936. Närpiön ja Oulujoen kivikauden hyljelöydöt. Suomen Museo, 43:1-37.

LindQvist, C. 1988. A carbonized cereal grain (Hordeum sp.) and faunal remains of e.g. harp seal (Phoca groenlandica), cod (Gadus morbua) and herring (Clupea harengus), from the Kolsvidja upper Stone Age habitation site on Aland. Finskt Museum 95:5-40. 
Lindqvist, C., AND G. Possnert. 1997. The subsistence economy and diet at Jakobs/Ajvide, Eksta parish and other prehistoric dwelling and burial sites on Gotland in long-term perspective. Pages 29-90 in G. Burenhult ed. Remote sensing. Volume I. Osteoanthropological, economic, environmental and technical analyses. Theses and Papers in North-European Archaeology 13a. Hässleholm, Sweden.

LINDQVIST, S. 1916. En uppländsk gårdsanläggning från stenåldern. Fornvännen 11: $164-180$.

LõUgas, L. 1997a. Post-glacial development of vertebrate fauna in Estonian water bodies. A palaeozoological study. Dissertationes Biologicae Universitatis Tartuensis 32. Tartu University Press, Tartu, Estonia.

LõUgAS, L. 1997b. Subfossil seal finds from archaeological coastal sites in Estonia, east part of the Baltic Sea. Anthropozoologica 25-26:699-706.

Lõugas, L. 1998. Postglacial invasions of the harp seal (Pagophilus groenlandicus Erxl. 1777) into the Baltic Sea. Proceedings of the Latvian Academy of Sciences. B: Natural, Exact, and Applied Sciences 52:63-69.

Lõugas, L., K. Lidén AND D. E. Nelson. 1996. Resource utilisation along the Estonian Coast during the Stone Age. Pages 399-420 in T. Hackens, S. Hicks, V. Lang, U. Miller and L. Saarse, eds. Coastal Estonia: Recent advances in environmental and cultural history. PACT-Journal of the European Network of Scientific and Technical Cooperation for the Cultural Heritage 51.

Lubicz-NieZABITOwsKi, E. 1928. Szczatki zwierzece z osady neolitycznej w Rzucewie na polskim wybrzezu Baltyku. Przeglad Archeologiczny 3:64-81. (With summary in German).

Madsen, A. P., S. Müller, C. Neergaard, C. G. Joh. Petersen, E. Rostrup, K. J. V. SteEnstrup and H. Winge. 1900. Affaldsdynger fra Stenalderen i Danmark unders $\varnothing$ gte for Nationalmuseet. Thieles Bogtryckeri, Copenhagen, Denmark.

Mathiassen, T., M. Degerbøl and J. Troels-Smith. 1942. Dyrholmen. En stenalderboplads paa Djursland. Det Kongelige Danske Videnskabernes Selskab. ArkæologiskKunsthistoriske Skrifter 1. Copenhagen, Denmark.

McLeAN, D. M. 1986. Embryogenesis dysfunction in the Pleistocene/Holocene transition mammalian extinctions, dwarfing, and skeletal abnormality. The Quaternary of Virginia. A Symposium Volume Publication 75:105-120.

McLean, D. M. 1988. Climatic warming and mammalian evolution/extinctions. The Global Environmental Protection Act of 1988. U. S. Senate, Washington, DC. Publication 100-843:102-113.

McLeAN, D. M. 1991. A climate change mammalian population collapse mechanism. Pages 93-100 in Kainlauri, E., A. Johansson, I. Kurki-Suonio, and M. Geshwiler eds. Energy and environment. American Society of Heating, Refrigerating and Air-conditioning Engineers, New York, NY.

MøHL, U. 1957. Zoologisk gennemgang af knoglematerialet fra jernalderbopladserne Dalshøj og Sorte Muld, Bornholm. Pages 279-318 in Klindt-Jensen, O., Bornholm i folkevandringstiden. Nationalmuseets skrifter, St $\varnothing$ rre beretninger II, Copenhagen, Denmark.

MøHL, U. 1970. Fangstdyrene ved de danske strande. Den zoologiske baggrund for harpunerne. KUML 1970:297-329.

MøHL, U. 1971. Oversigt over dyreknoglerne fra Ølby Lyng. En østsjællandsk kystboplads med Ertebøllekultur. Aarbøger for nordisk Oldkyndighet og Historie 1970:43-77.

NihléN, J. 1927. Gotlands stenåldersboplatser. Kungliga Vitterhets Historie och Antikvitetsakademiens Handlingar 36:3.

Olson, C. 1999. Osteologisk rapport Vedmora RAÄ 145 Enånger socken, Hälsingland (1997). Pages 91-102 in M. Björck and N. Björck. Vedmora en gropkeramisk boplats. Arkeologisk undersökning RAÄ 145 Enångers socken, Hälsingland 1996. RapportLänsmuseet Gävleborg 1999:02. Gävle, Sweden. 
Olsson, E., G. Granath Zillén and A. Mohr. 1994. Korsnäs. En gropkeramisk grav- och boplats på Södertörn. UV Stockholm rapport 1994:63. Stockholm, Sweden.

PIRA, A. 1926. On bone deposits in the cave "Stora Förvar" on the isle of Stora Karlsö, Sweden. A contribution to the knowledge of prehistoric domestic animals. Acta Zoologica 7:123-217.

Salmi, M. 1963. Drei subfossile Sattelrobben aus Ostbottnien. Geologische Datierung der Funde und einige chronologische Beobachtungen. Archivum Societatis zoologicae botanicae Fennicae Vanamo 18:82-95.

Schnell, I. 1930. Södertörn under Stenåldern. Bidrag till Södermanlands äldre kulturhistoria 24:7-54.

Segerberg, A. 1999. Bälinge mossar. Kustbor i Uppland under yngre stenåldern. Aun 26. Uppsala Universitet, Uppsala, Sweden.

Sergeant, D. E. 1991. Harp seals, man and ice. Canadian Special Publication of Fisheries and Aquatic Sciences 114.

Stenderger, M., E. Dahr and H. Munthe. 1943. Das Grabfeld von Västerbjers auf Gotland. Monografier 30, Konliga Vitterhets Historie och Antikvitets Akademien, Stockholm, Sweden.

STOR̊̊, J. 2000. Sealing and animal husbandry in the Ålandic Middle and Late Neolithic. Fennoscandia Archaeologica XVII:57-81.

StORA, J. 2001. Skeletal development in the Grey seal Halichoerus grypus, the ringed seal Phoca hispida botnica, the harbour seal Phoca vitulina vitulina and the harp seal Phoca groenlandica. Epiphyseal fusion and life history. Pages 199-211 in A. Pike-Tay, ed. Innovations in assessing season of capture, age and sex of archaeofaunas. ArchaeoZoologia, XI/1.2. La Pensée Sauvage, Grenoble, Switzerland.

StORÅ, J. 2002. Seal hunting on Ajvide. A taphonomic study of seal remains from a Pitted Ware Culture site on Gotland. Pages 387-428 in G. Burenhult, ed. Remote sensing. Volume II. Archaeological investigations, remote sensing case studies and osteoanthropological studies. Theses and Papers in North-European Archaeology 13b, Hässleholm, Sweden.

WaLLIN, P., AND T. ERIKSSON. 1985. Osteologisk analys av djur- och människoben från stenåldersboplatsen i Visby på Gotland. BA thesis in Archaeoosteological Research Laboratory, Stockholm University, Stockholm, Sweden. 52 pp.

Wallin, P., AND H. Martinsson-Wallin. 1996. Åter till Hemmorboplatsen-utgrävningar, analyser och reflexioner. Gotländskt Arkiv 68:7-28.

WIIG, Ø. 1988. Selinvasjoner til Norske kyster. Fiskets Gang 74:18-19.

Winge, H. 1904. Om jordfundne pattedyr fra Danmark. Videnskabelige Meddelelser fra den naturhistoriske Forening i Kjøbenhavn for Aaret 1904. Copenhagen, Denmark.

WINGE, H. 1914. Knogler fra en stenalderbopladts vid Jettböle, Åland. Unpublished report in the archives of the Bureau of Antiquities, FIN-22101 Mariehamn, Finland.

Ylimaunu, J. 2000. Itämeren hylkeenpyyntikulttuurit ja ihminen-hyljesuhde. Suomalaisen Kirjallisuuden Seura, Toimituksia 773, Helsinki, Finland.

ZAGORSKA, I. 2000. Sea mammal hunting strategy in eastern Baltic. Lietuvos Archeologija 19:275-285. 